\title{
Children's mental health and collective \\ violence: a binational study on the United States-Mexico border
}

\author{
Marie Leiner, ${ }^{1}$ Hector Puertas, ${ }^{2}$ Raúl Caratachea, ${ }^{2}$ Carmen Avila, ${ }^{3}$ \\ Aparna Atluru, ${ }^{1}$ David Briones, ${ }^{1}$ and Cecilia de Vargas ${ }^{1}$
} $\begin{array}{ll}\text { Suggested citation } & \text { Leiner M, Puertas H, Caratachea R, Avila C, Atluru A, Briones D, de Vargas C. Children's mental } \\ \text { health and collective violence: a binational study on the United States-Mexico border. Rev Panam }\end{array}$ Salud Publica. 2012;31(5):411-6.

ABSTRACT Objective. To investigate the risk effects of poverty and exposure to collective violence attributed to organized crime on the mental health of children living on the United StatesMexico border.

Methods. A repeated, cross-sectional study measured risk effects by comparing scores of psychosocial and behavioral problems among children and adolescents living on the border in the United States or Mexico in 2007 and 2010. Patients living in poverty who responded once to the Pictorial Child Behavior Checklist $(P+C B C L)$ in Spanish were randomly selected from clinics in El Paso, Texas, United States (poverty alone group), and Ciudad Juarez, Chihuahua, Mexico (poverty plus violence group). Only children of Hispanic origin (Mexican-American or Mexican) living below the poverty level and presenting at the clinic for nonemergency visits with no history of diagnosed mental, neurological, or life-threatening disease or disability were included.

Results. Exposure to collective violence and poverty seemed to have an additive effect on children's mental health. Children exposed to both poverty and collective violence had higher problem scores, as measured by the P+CBCL, than those exposed to poverty alone.

Conclusions. It is important to consider that children and adolescents exposed to collective violence and poverty also have fewer chances to receive treatment. Untreated mental health problems predict violence, antisocial behaviors, and delinquency and affect families, communities, and individuals. It is crucial to address the mental health of children on the border to counteract the devastating effects this setting will have in the short term and the near future.

Key words Child behavior; adolescent health; violence; mental health; poverty; crime; border health; United States; Mexico.

Among other factors, including genetics, material deprivation is considered to

\footnotetext{
Department of Psychiatry, Texas Tech University Health Sciences Center, El Paso, Texas, United States of America. Send correspondence to: Marie Leiner, marie.leiner@ttuhsc.edu

2 Dirección de Servicios de Salud de Chihuahua, Jurisdicción Sanitaria II, Secretaria de Salud, Ciudad Juárez, Chihuahua, México.

3 El Colegio de Chihuahua, Estudios de Comunicación: Salud, Educación y Ambiente Laboral, Cuidad Juárez, Chihuahua, México.
}

have a detrimental effect on youth mental health. Poverty is linked to strenuous circumstances that can be additive sources of risk, such as parents' lack of education, poor physical and mental health, conflicting relationship issues (including familial struggles), and lack of employment or income (1). Economic adversity is also associated with social and environmental degradation, which contribute independently or individually to potentiate mental health risks. Exposures to community violence, hostile environments, and lack of resources can create undesired conditions in the mental health of individuals and families $(2,3)$.

Many children and adolescents in poorer countries and communities assume adult responsibilities while still in 
early development, including working and taking care of younger siblings. To subsist, their parents often need to work long hours at minimum pay, leaving their children to confront adultlike roles and exposing the children to higher risks for psychosocial and behavioral problems. This higher risk affects the children's health; it starts early, tends to persist into adolescence and adulthood, and includes poor physical health (4), antisocial behavior (5), juvenile delinquency $(6)$, adult crime $(7,8)$, and an array of social problems (9-12). Susceptibility to mental health risk factors varies with age and gender, but the effects depend on the duration of risk and the simultaneous occurrence of the risk factors. Multiple risks occurring at once have a cumulative effect $(13,14)$.

Cumulative adverse events contribute to a higher vulnerability of children exposed to traumatic experiences (15). Several studies have indicated that exposure to community violence, including armed conflicts and war (16-21) as well as gangs $(22,23)$, has profound detrimental effects on children (24-27).

Poverty alone is a predictor of problems among children, with long-lasting effects, and poverty plus exposure to collective violence has been recognized to have a cumulative effect (28, 29). However, studies that examined the effects of both poverty and collective violence (attributed to organized crime) could not be found. The objective of this study was to investigate the risk effects of poverty and exposure to collective violence attributed to organized crime on the mental health of children living on the U.S.-Mexico border. The mental health of children living in poverty in a population of Mexican Americans in El Paso, Texas, United States, was compared with a population of Mexican children living in poverty and exposed to collective violence attributed to organized crime in Ciudad Juarez, Chihuahua, Mexico. Comparison of children living on each side of this border region provides a natural environment for studying the interaction of poverty and community violence. El Paso is rated one of the safest major cities in the United States (30) in terms of exposure to crime, while Ciudad Juarez was characterized as the most violent city in the world for three years running (31).

\section{METHODS AND MATERIALS}

\section{Type of study}

This is a repeated cross-sectional study, with data collected in 2007 and 2010 in two border cities in the United States and Mexico.

\section{Participants}

A total of 1261 participants were included in this study, with 466 (233 in the United States and 233 in Mexico) participants in 2007 and 795 (397 in the United States and 398 in Mexico) in 2010. Participant information was extracted from electronic record databases maintained in six university-based clinics in the United States and nine clinics of the Secretaria de Salud in Mexico.

\section{Database information characteristics}

U.S. electronic information. This large electronic database contained more than 7000 pediatric patients whose parents responded to a psychosocial and behavioral assessment known as the Pictorial Child Behavior Checklist (P+CBCL). Parents and caretakers responded to the selfresponse $\mathrm{P}+\mathrm{CBCL}$ during nonemergency health care visits when the children were receiving routine pediatric care.

Mexican electronic information. Parents and caretakers replied to the selfresponse $\mathrm{P}+\mathrm{CBCL}$ during nonemergency health care visits, when the children were receiving routine care in these clinics.

Information available in the two databases included date of assessment, gender, age, and total scores of the P+CBCL.

\section{Inclusion criteria}

Only parents who reported Hispanic ethnicity and who responded to the $\mathrm{P}+\mathrm{CBCL}$ questionnaire in Spanish were sampled from the electronic records in the United States. A second criterion for being sampled from the U.S. database was that family income had to be below the poverty level. Because the six clinics in the United States served mainly lowincome Hispanic children, these two criteria for participation excluded $<5 \%$ of the patients. In the U.S. database overall, $78 \%$ of the families were on Medicaid, $17 \%$ were on the Children's Health In- surance Program, and 5\% had no insurance. The sample of Mexican children included those who responded to the $\mathrm{P}+\mathrm{CBCL}$ in Spanish who had Seguro Popular, an insurance program provided by the government of Mexico to extend insurance to cover health services including routine and preventive medical care, pharmaceuticals, and health facilities to 50 million uninsured Mexicans in the lowest socioeconomic bracket (32).

Electronic data from Mexican clinics containing records without identifiers were provided with authorization of the Secretaria de Salud, Jurisdiction Sanitaria II ethics committee, for analysis. In the United States, authorization to extract information from medical records without identifiers was approved by the Institutional Review Board at Texas Tech University Health Sciences Center.

\section{Measures}

P+CBCL. The P+CBCL (33) is an adaptation of the original CBCL (34), which was developed to support parents with limited literacy. High test-retest reliability (e.g., mean $r=0.90$ for empirically based scales) and strong internal consistency (e.g., $\alpha=0.97$ for the total problems score) have been reported for the CBCL (35), and the P+CBCL used in this study has shown psychometric equivalence with the CBCL. Past research demonstrated the validity and reliability of the CBCL in clinical settings (6). The CBCL has been validated among children living in Mexico (36-38), has been used in many other Latin American countries, and demonstrated remarkable consistency in its psychometric properties across more than 30 countries (39). The P+CBCL contains 120 behavioral and emotional problem items that are scored on a 3 -point scale $(0=$ not true, 1 = somewhat or sometimes true, $2=$ very true or often true). Factor analysis of this assessment tool yields eight problem scales, of which three (anxious/depressed, withdrawn/depressed, and somatic complaints) load onto the broadband internalizing scale, and two (rule breaking and aggressive behavior) load onto the broadband externalizing scale. The other three problem scales (social problems, thought problems, and attention problems) do not load differentially onto either broadband scale. A total problem score is computed by summing all problem items, and 
$T$ scores are calculated for each scale. However, for this study, only raw scores for each of the eight problem scales were used (anxious/depressed, withdrawn/ depressed, somatic complaints, rule breaking, aggressive behavior, social problems, and thought and attention problems).

Crime rates of drug-related killings. The rate of drug-related killings (31) for 2007 was 0 per 100000 people in Ciudad Juarez and in El Paso. For 2010, the rate was 229.1 per 100000 people in Ciudad Juarez, and in 2010 the rate in El Paso remained at 0 per 100000 people.

Statistical methods. All statistical analyses were done with SPSS, version 18 (IBM). Demographic variables were reported using frequencies for continuous variables and cross-tabulations for categorical variables. $T$-test analysis was used to compare mean scores between groups by year in the United States and Mexico. The effects of time (2007 or 2010), place of residence (United States or Mexico), gender (male or female), and age group $(6-9,10-12$, or $\geq 13$ years) were examined by using a series of eight mixed-model analyses of variance (ANOVAs) with a $2 \times 2 \times 2 \times 3$ design. The Bonferroni correction for multiple comparisons was applied to the nine ANOVAs, which were all evaluated at the $P=0.006$ (i.e., $0.05 / 9$ ) level. Effect sizes (Cohen's $d$ ) were also calculated. Guidelines for interpretation were: $0.2=$ small, $0.5=$ medium, and $0.8=$ large (40).

\section{RESULTS}

The demographics of the four samples are presented in Table 1 . There was no apparent difference between age groups or gender among the United States and Mexico groups in 2007 and 2010. Raw scores of the P+CBCL among the four groups and the two years indicate that higher scores in all problem scales corresponded to Mexican children in 2010 (see Table 2). When comparing the U.S. mean scores in 2007 with those in 2010, there was only one significant difference in somatic complaint problem scores, with a higher score reported in 2007. At the Mexican site, when comparing scores between 2007 and 2010, there were significant differences for three scales: the social problem, rule breaking, and aggressive behavior problem scales, with higher scores reported in 2010.

TABLE 1. Demographic characteristic frequency of $P+C B C L$ respondents in United States and Mexico, 2007 and 2010

\begin{tabular}{|c|c|c|c|c|}
\hline \multirow[b]{2}{*}{ Variable } & \multicolumn{2}{|c|}{ United States } & \multicolumn{2}{|c|}{ Mexico } \\
\hline & $\begin{array}{c}2007 \\
(n=233)\end{array}$ & $\begin{array}{c}2010 \\
(n=398)\end{array}$ & $\begin{array}{c}2007 \\
(n=233)\end{array}$ & $\begin{array}{c}2010 \\
(n=397)\end{array}$ \\
\hline \multicolumn{5}{|c|}{ Age group (years) } \\
\hline \multicolumn{5}{|l|}{$6-9$} \\
\hline Number & 75 & 172 & 75 & 171 \\
\hline Percent & 32.2 & 43.2 & 32.2 & 43.1 \\
\hline \multicolumn{5}{|l|}{$10-12$} \\
\hline Number & 70 & 124 & 70 & 124 \\
\hline Percent & 30.0 & 31.2 & 30.0 & 31.2 \\
\hline \multicolumn{5}{|l|}{$\geq 13$} \\
\hline Number & 88 & 102 & 88 & 102 \\
\hline Percent & 37.8 & 25.6 & 37.8 & 25.7 \\
\hline \multicolumn{5}{|l|}{ Gender } \\
\hline \multicolumn{5}{|l|}{ Male } \\
\hline Number & 119 & 200 & 118 & 210 \\
\hline Percent & 51.1 & 50.3 & 50.6 & 52.9 \\
\hline
\end{tabular}

Note: P+CBCL: Pictorial Child Behavior Checklist.

TABLE 2. Comparative mean scores of problem raw scale scores between United States and Mexico, 2007 and 2010

\begin{tabular}{lccccc}
\hline & \multicolumn{2}{c}{ United States } & & \multicolumn{2}{c}{ Mexico } \\
\cline { 2 - 3 } \cline { 5 - 6 } Problem scale score & $\begin{array}{c}2007 \\
(n=233)\end{array}$ & $\begin{array}{c}2010 \\
(n=398)\end{array}$ & & $\begin{array}{c}2007 \\
(n=233)\end{array}$ & $\begin{array}{c}2010 \\
(n=397)\end{array}$ \\
\hline Anxious/depressed & 2.9 & 2.7 & & 4.3 & 4.7 \\
Withdrawn/depressed & 1.7 & 1.5 & & 2.8 & 2.8 \\
Somatic complaints & $2.6^{\mathrm{a}}$ & 2.1 & & 3.2 & 3.1 \\
Social problems & 2.2 & 2.1 & & 4.1 & $4.8^{\mathrm{b}}$ \\
Thought problems & 1.5 & 1.4 & & 2.3 & 2.6 \\
Attention problems & 3.2 & 3.1 & & 5.1 & 5.7 \\
Rule-breaking behavior & 1.7 & 1.4 & & 2.9 & $3.8^{\mathrm{c}}$ \\
Aggressive behavior & 5.0 & 4.3 & & 8.0 & $9.8^{\mathrm{c}}$ \\
\hline a $P=0.03$. & & & & \\
b $P=0.01$. & & & & & \\
c $P<0.001$. & & & & &
\end{tabular}

There were significant effects of group (United States or Mexico) for all the problem scales (anxious/depressed, withdrawn/depressed, somatic complaints, rule breaking, aggressive behavior, social problems, and thought and attention problems), but all effect sizes were small; the direction of the group effect indicated higher scores in Mexico. Effects by age groups (6-9, 10-12, or $\geq 13$ years) were significant, with higher scores among younger children in withdrawn/ depressed and social and attention problems (small effect sizes). Aggressive behavior problem effects were found to be higher in older children, with small effect sizes. Gender effects (male/female) were found, with the effect direction toward higher scores for boys when compared with girls in rule breaking, aggressive behavior, and attention problems (all effect sizes were small). There were significant effects in the interaction of group (United States or Mexico) and year (2007 or 2010) in rule breaking, aggressive behavior, and social problems, with the effect direction showing higher scores in Mexico in 2010 with medium effect sizes in social problems and small effects in the rest of the problem scales. Additionally, there was an interaction between group (United States or Mexico), year (2007 or 2010), and age groups $(6-9,10-12$, or $\geq 13$ years) in somatic and social scale problems, with the effect direction toward children 6-9 years old in Mexico having the higher scores (effect sizes were small).

\section{DISCUSSION}

The objective of this is study was to investigate the risk effects of poverty and exposure to collective violence attributed to organized crime on the mental health of children living on the U.S.-Mexico border. Raw scores were used instead of $T$ scores to compare the groups in this study to look at differences derived 
exclusively from the parent responses to the $\mathrm{P}+\mathrm{CBCL}$ in the four groups.

Comparing psychosocial and behavioral scale scores in the United States, children and adolescents between 2007 and 2010 did not yield a significant difference in problem scale scores, with the exception of somatic complaint scores. In Mexico, there were significant differences in problem scale scores when comparing 2007 and 2010, with higher scores reported in 2010.

The significant resulting interaction between groups (United States or Mexico) and times (2007 or 2010), with higher scores reported for children and adolescents living in Mexico in 2010 in rule breaking, aggressive behavior, and social problem scales, seem to indicate an additive effect of poverty plus exposure to collective violence in this group. Vulnerability of younger children in somatic and social problem scales was found among children in Mexico in 2010 in the youngest group as a result of the interaction between group (United States or Mexico), year (2007 or 2010), and age group (6-9, $10-12$, or $\geq 13$ years), although the effect sizes were small. These findings seem to indicate that problems reported by parents have increased in 2010 in a city that has been considered one of the most violent cities in the world not at war.

According to published data, drugrelated violence in Mexico has escalated at an unprecedented rate in the past 5 years. Assassinations in Mexico have increased, with thousands of drug-related deaths occurring in Ciudad Juarez, sister city to El Paso (31).

Families in this border area face strenuous consequences resulting from the loss of family members through death, torture, and kidnapping and constant exposure to violence through television and radio reports that is detrimental to children (34) and families (41). Mental health providers in El Paso have seen increased numbers of Juarez children and adolescents who cross the border in search of help for psychiatric and psychological problems resulting from the effects of gang wars in their country (personal communications in weekly meetings, 2011).

Chronic exposure of children to violence has been shown to trigger a panoply of serious mental health problems, often manifested by depression, anxiety, acute stress disorder, post-traumatic stress disorder, sleep difficulties, somatic symptoms, complicated bereavement, substance abuse, and antisocial and suicidal behaviors, among others (42-45). Studies addressing violencerelated trauma in Cambodian youth from the Thai-Cambodian border (46-48) and children and adolescents on Israel's northern border (49), South Africa (39, 50), Kosovo (51-53), Palestine (54-57), Sri Lanka $(15,58)$, Afghanistan $(15,59)$, and Rwanda (60-62) confirmed the presence of mental health problems in pediatric populations exposed to violent trauma.

This study has some limitations, including the lack of measurement of concurrent intrafamilial violence, child abuse, and other types of violence that confronted children at the time of the study, which could contribute independently to the mental health of children. Personal experiences were not quantified, which could confound the final results of this study. Personal experiences of the families as victims and experiences of witnessing or learning about incidents were not included in this study. Poverty levels in the groups could be different, despite an attempt to compare children of similar socioeconomic status. It is possible that children living in poverty in Mexico are poorer than children living in poverty in the United States, and that difference could have an effect on the problems reported. Despite these limitations, the results of this study show high rates of mental health problems in children in this area, in both the United States and Mexico. The higher rates of psychosocial and behavioral problems for the children on the Mexican side of the border during 2010 show evidence of the additive effect of poverty plus exposure to collective violence, although economic, social, and cultural factors cannot be ruled out.

\section{RECOMMENDATIONS}

Planning for the mental health needs of children in the future is an imperative that has not been sufficiently addressed. El Paso is located in a socioeconomically deprived area that traditionally has not included long-term plans for screening and assessing the mental health needs of children. Texas, California, and Florida traditionally have rates of unmet mental health needs that differ significantly from the national average $[P<0.05$ according to the 1997 and 1999 waves of the National Survey of America's Families (63)]. Because of collective violence attributed to organized crime, Ciudad Juarez is confronting economic and political challenges that affect the population from different perspectives. Children in this area are at higher risk for mental health problems, and programs to alleviate their mental health problems might not be available because of difficulty in understanding the dimensions of the problems the children face.

Children need advocates everywhere, but the children of this border region need the combined or individual effort of two countries, policymakers, parents, mental health professionals, and the entire community to counteract the devastating effects this setting will have in the short term and the near future.

\section{REFERENCES}

1. Wille N, Bettge S, Ravens-Sieberer U, BELLA Study Group. Risk and protective factors for children's and adolescents' mental health: results of the BELLA study. Eur Child Adolesc Psychiatry. 2008;17(Suppl 1):133-47.

2. UNICEF Innocenti Research Centre. Child poverty in rich countries, 2005, part I. Int J Health Serv. 2006;36(2):235-69.

3. UNICEF Innocenti Research Centre. Child poverty in rich countries, 2005, Part II. Int J Health Serv. 2006;36(3):455-79.
4. Akinbami LJ, Moorman JE, Liu X. Asthma prevalence, health care use, and mortality: United States, 2005-2009. Natl Health Stat Report. 2011;12(32):1-14.

5. Gatti U, Tremblay RE, Vitaro F. Iatrogenic effect of juvenile justice. J Child Psychol Psychiatry. 2009;50(8):991-8.

6. Eamon MK, Mulder C. Predicting antisocial behavior among Latino young adolescents: an ecological systems analysis. Am J Orthopsychiatry. 2005;75(1):117-27.
7. Zielinski DS. Child maltreatment and adult socioeconomic well-being. Child Abuse Negl. 2009;33(10):666-78.

8. Spano R, Vazsonyi AT, Bolland J. Does parenting mediate the effects of exposure to violence on violent behavior? An ecologicaltransactional model of community violence. J Adolesc. 2009;32(5):1321-41.

9. Herrenkohl TI, Kosterman R, Hawkins JD, Mason WA. Effects of growth in family conflict in adolescence on adult depressive symp- 
toms: mediating and moderating effects of stress and school bonding. J Adolesc Health. 2009;44(2):146-52

10. Murdock KK, Robinson EM, Adams SK, Berz J, Rollock MJ. Family-school connections and internalizing problems among children living with asthma in urban, low-income neighborhoods. J Child Health Care. 2009;13(3): 275-94.

11. Obradović J, Long JD, Cutuli JJ, Chan CK, Hinz E, Heistad D, et al. Academic achievement of homeless and highly mobile children in an urban school district: longitudinal evidence on risk, growth, and resilience. Dev Psychopathol. 2009;21(2):493-518.

12. Riley AW, Coiro MJ, Broitman M, Colantuoni E, Hurley KM, Bandeen-Roche K, et al. Mental health of children of low-income depressed mothers: influences of parenting, family environment, and raters. Psychiatr Serv. 2009;60(3):329-36

13. Appleyard $\mathrm{K}$, Egeland B, van Dulmen $\mathrm{MH}$ Sroufe LA. When more is not better: the role of cumulative risk in child behavior outcomes. J Child Psychol Psychiatry. 2005;46(3):235-45.

14. Evans GW. A multimethodological analysis of cumulative risk and allostatic load among rural children. Dev Psychol. 2003;39(5):924-33.

15. Catani C, Schauer E, Elbert T, Missmahl I, Bette JP, Neuner F. War trauma, child labor, and family violence: life adversities and PTSD in a sample of school children in Kabul. J Trauma Stress. 2009;22(3):163-71.

16. Thabet AA, Ibraheem AN, Shivram R, Winter EA, Vostanis P. Parenting support and PTSD in children of a war zone. Int J Soc Psychiatry. 2009;55(3):226-37.

17. Panter-Brick C, Eggerman M, Gonzalez V, Safdar S. Violence, suffering, and mental health in Afghanistan: a school-based survey. Lancet. 2009;374(9692):807-16.

18. Levy BS, Sidel VW. Health effects of combat: a life-course perspective. Annu Rev Public Health. 2009;30:123-36.

19. Espié E, Gaboulaud V, Baubet T, Casas G, Mouchenik Y, Yun O, et al. Trauma-related psychological disorders among Palestinian children and adults in Gaza and West Bank, 2005-2008. Int J Ment Health Syst. 2009; 3(1):21.

20. Betancourt TS, Speelman L, Onyango G, Bolton P. A qualitative study of mental health problems among children displaced by war in northern Uganda. Transcult Psychiatry. 2009;46(2):238-56.

21. Attanayake V, McKay R, Joffres M, Singh S, Burkle F Jr., Mills E. Prevalence of mental disorders among children exposed to war: a systematic review of 7,920 children. Med Confl Surviv. 2009;25(1):4-19.

22. Douyon R, Herns Marcelin L, Jean-Gilles M, Page JB. Response to trauma in Haitian youth at risk. J Ethn Subst Abuse. 2005;4(2):115-38.

23. Kee C, Sim K, Teoh J, Tian CS, Ng KH. Individual and familial characteristics of youths involved in street corner gangs in Singapore. J Adolesc. 2003;26(4):401-12.

24. Cooley-Strickland M, Quille TJ, Griffin RS, Stuart EA, Bradshaw CP, Furr-Holden D. Community violence and youth: affect, behavior, substance use, and academics. Clin Child Fam Psychol Rev. 2009;12(2):127-56.

25. Benjet C, Borges G, Medina-Mora ME, Zambrano J, Cruz C, Mendez E. Descriptive epidemiology of chronic childhood adversity in Mexican adolescents. J Adolesc Health. 2009;45(5):483-9.

26. Concha-Eastman A, Krug E. Informe mundial sobre la salud y la violencia de la OMS: una herramienta de trabajo. Rev Panam Salud Publica. 2002;12(4):227-9.

27. Concha A. Impacto social y económico de la violencia en las Américas. Biomedica. 2002;22(Suppl 2):347-61.

28. Dubow EF, Boxer P, Huesmann LR, Shikaki K, Landau S, Gvirsman SD, et al. Exposure to conflict and violence across contexts: relations to adjustment among Palestinian children. J Clin Child Adolesc Psychol. 39(1):103-16.

29. Malik NM. Exposure to domestic and community violence in a nonrisk sample: associations with child functioning. J Interpers Violence. 2008;23(4):490-504

30. KVIA. El Paso ranks safest city in US: city safest for populations over 500,000. 2010. Available from: http://www.kvia.com/ news/25870470/detail.html Accessed 21 March 2011.

31. University of San Diego. Crime indicator database for the justice in Mexico project at the Trans-Border Institute. San Diego: University of San Diego; 2011

32. King G, Gakidou E, Ravishankar N, Moore RT, Lakin J, Vargas M, et al. Politically robust experimental design for public policy evaluation, with application to the Mexican universal health insurance program. J Policy Anal Manage. 2007;26(3):479-506.

33. Leiner M, Rescorla L, Medina I, Blanc O, Ortiz M. Psychometric comparisons of the Pictorial Child Behavior Checklist with the standard version of the instrument. Psychol Assess. 2010;22(3):618-27.

34. Leiner M. Niñez en riesgo: el impacto de la violencia en Ciudad Juárez. Ciudad Juárez, Chihuahua: El Colegio de Chihuahua; 2010.

35. Pagano M, Murphy JM, Pedersen M, Mosbacher D, Crist-Whitzel J, Jordan P, et al. Screening for psychosocial problems in 4-5-year-olds during routine EPSDT examinations: validity and reliability in a MexicanAmerican sample. Clin Pediatr (Phila). 1996; 35(3):139-46.

36. Albores-Gallo L, Lara-Muñoz C, EsperónVargas C, Cárdenas Zetina JA, Pérez Soriano AM, Villanueva Colin G. Validity and reliability of the CBCL/6-18. Includes DSM scales. Actas Esp Psiquiatr. 2007;35(6):393-9.

37. Albores-Gallo L, Sauceda-García JM, RuizVelasco S, Roque-Santiago E. El acoso escolar (bullying) y su asociación con trastornos psiquiátricos en una muestra de escolares en México. Salud Publica Mex. 2010;53(3): 220-7.

38. Leiner MA, Balcazar H, Straus DC, Shirsat P, Handal G. Screening Mexicans for psychosocial and behavioral problems during pediatric consultation. Rev Invest Clin. 2007;59(2):116-23.

39. Ivanova MY, Dobrean A, Dopfner M, Erol N, Fombonne E, Fonseca AC, et al. Testing the 8-syndrome structure of the child behavior checklist in 30 societies. J Clin Child Adolesc Psychol. 2007;36(3):405-17

40. Cohen J. Statistical power analysis for the behavioral sciences. 2nd ed., Hillsdale, NJ: Lawrence Erlbaum Associates; 1988.

41. Turati M. Fuego cruzado. Mexico City: Grijalbo; 2011.
42. Fremont WP. Childhood reactions to terrorism-induced trauma: a review of the past 10 years. J Am Acad Child Adolesc Psychiatry. 2004;43(4):381-92.

43. Feldman R, Vengrober A. Posttraumatic stress disorder in infants and young children exposed to war-related trauma. J Am Acad Child Adolesc Psychiatry. 2011;50(7):645-58.

44. Murthy RS. Mass violence and mental health-recent epidemiological findings. Int Rev Psychiatry. 2007;19(3):183-92.

45. Veenema TG, Schroeder-Bruce K. The aftermath of violence: children, disaster, and posttraumatic stress disorder. J Pediatr Health Care. 2002;16(5):235-44.

46. Savin D, Sack WH, Clarke GN, Meas N, Richart I. The Khmer Adolescent Project: III. A study of trauma from Thailand's Site II refugee camp. J Am Acad Child Adolesc Psychiatry. 1996;35(3):384-91.

47. Buckner JC, Beardslee WR, Bassuk EL. Exposure to violence and low-income children's mental health: direct, moderated, and mediated relations. Am J Orthopsychiatry. 2004;74(4):413-23.

48. Mollica RF, Poole C, Son L, Murray CC, Tor S. Effects of war trauma on Cambodian refugee adolescents' functional health and mental health status. J Am Acad Child Adolesc Psychiatry. 1997;36(8):1098-106.

49. Klingman A, Wiesner E. The relationship of proximity to tension areas and size of settlement to fear levels of Israeli children. J Behav Ther Exp Psychiatry. 1982;13(4):321-3.

50. Seedat S, Nyamai C, Njenga F, Vythilingum B, Stein DJ. Trauma exposure and posttraumatic stress symptoms in urban African schools. Survey in CapeTown and Nairobi. Br J Psychiatry. 2004;184:169-75.

51. Baràth A. Children's well-being after the war in Kosovo: survey in 2000. Croat Med J. 2002;43(2):199-208.

52. Grgić M, Vidović V, Butković-Soldo S, VuksićMihaljević Z, Degmecić D, Laufer D. The mental health of children upon their return home after a long displacement period. Coll Antropol. 2005;29(2):537-42.

53. Jones L, Rrustemi A, Shahini M, Uka A. Mental health services for war-affected children: report of a survey in Kosovo. Br J Psychiatry. 2003;183:540-6.

54. Braun-Lewensohn O, Sagy S. Coping resources as explanatory factors of stress reactions during missile attacks: comparing Jewish and Arab adolescents in Israel. Community Ment Health J. 2011;47(3):300-10.

55. Braun-Lewensohn O, Sagy S, Roth G. Coping strategies among adolescents: Israeli Jews and Arabs facing missile attacks. Anxiety Stress Coping. 2010;23(1):35-51.

56. Hundt GL, Chatty D, Thabet AA, Abuateya H. Advocating multi-disciplinarity in studying complex emergencies: the limitations of a psychological approach to understanding how young people cope with prolonged conflict in Gaza. J Biosoc Sci. 2004;36(4): 417-31.

57. Khamis V. Post-traumatic stress and psychiatric disorders in Palestinian adolescents following Intifada-related injuries. Soc Sci Med. 2008;67(8):1199-207.

58. Jordans MJ, Komproe IH, Tol WA, De Jong JT. Screening for psychosocial distress amongst war-affected children: cross-cultural con- 
struct validity of the CPDS. J Child Psychol Psychiatry. 2009;50(4):514-23.

59. Catani C, Schauer E, Neuner F. Beyond individual war trauma: domestic violence against children in Afghanistan and Sri Lanka. J Marital Fam Ther. 2008;34(2):165-76.

60. Neugebauer R, Fisher PW, Turner JB, Yamabe S, Sarsfield JA, Stehling-Ariza T. Post-traumatic stress reactions among Rwandan children and adolescents in the early aftermath of genocide. Int J Epidemiol. 2009;38(4):1033-45.

61. Kuper H, Atijosan O, Rischewski D, Simms V, Lavy C. A decade later, how much of Rwanda's musculoskeletal impairment is caused by the war in 1994 and by related violence? PLoS One. 2009;4(11):e7720.

62. Schaal S, Elbert T. Ten years after the genocide: trauma confrontation and posttraumatic stress in Rwandan adolescents. J Trauma Stress. 2006;19(1):95-105.

63. Sturm R, Ringel JS, Andreyeva T. Geographic disparities in children's mental health care. Pediatrics. 2003;112(4):e308.

Manuscript received on 29 July 2011. Revised version accepted for publication on 24 January 2012.

RESUMEN Objetivo. Investigar los efectos del riesgo de pobreza y la exposición a la violencia colectiva atribuida al crimen organizado sobre la salud mental de los niños que viven en la frontera entre México y los Estados Unidos.

Salud mental infantil y violencia colectiva: un estudio binacional en la frontera entre México y los Estados Unidos

Palabras clave
Métodos. En este estudio transversal seriado se midieron los efectos del riesgo mediante la comparación de las puntuaciones de problemas psicosociales y conductuales en los niños y adolescentes que viven en la frontera entre México y los Estados Unidos en el 2007 y el 2010. Se seleccionó aleatoriamente a pacientes que viven en la pobreza que habían respondido en una oportunidad anterior el Cuestionario de Comportamiento Infantil basado en Pictogramas $(\mathrm{P}+\mathrm{CBCL})$ en español a partir de consultorios en El Paso, Texas, Estados Unidos (grupo afectado solamente por la pobreza), y Ciudad Juárez, Chihuahua, México (grupo afectado por la pobreza y la violencia). Se incluyeron solamente niños de origen hispano (estadounidenses de origen mexicano o mexicanos) que vivían en la pobreza, que consultaron por motivos que no eran urgencias y que no presentaban antecedentes de enfermedades neurológicas, mentales o potencialmente mortales, ni discapacidad.

Resultados. La exposición a la violencia colectiva y la pobreza parecieron tener un efecto aditivo sobre la salud mental de los niños. Los niños expuestos tanto a la pobreza como a la violencia colectiva tuvieron puntuaciones mayores de problemas conductuales y psicosociales según las mediciones del P+CBCL que aquellos expuestos solamente a la pobreza.

Conclusiones. Es importante considerar que los niños y los adolescentes expuestos a la violencia colectiva y la pobreza también tienen menos oportunidades de recibir tratamiento. Los problemas de salud mental no tratados son factores predictivos de la violencia, los comportamientos antisociales y la delincuencia y afectan a las familias, a las comunidades y a los individuos. Es crucial abordar el tema de la salud mental de los niños en la región de la frontera a fin de contrarrestar los efectos devastadores que esta situación ocasionará a corto plazo y en el futuro cercano.

Conducta infantil; salud del adolescente; violencia; salud mental; pobreza; crimen; salud fronteriza; Estados Unidos; México. 